\title{
Consumer Behavior for Milk and Dairy Products as Daily Consumption Products in Every Household-The Case of Kosovo
}

\author{
Njazi Bytyqi1 ${ }^{*}$, Skender Muji ${ }^{2}$, Agim Rexhepi ${ }^{3}$ \\ ${ }^{1}$ Department of Agroeconomy, Faculty of Agriculture and Veterinary, University of Prishtina, Prishtina, Kosovo \\ ${ }^{2}$ Department of Biotechnology in Livestock, Faculty of Agriculture and Veterinary, University of Prishtina, Prishtina, Kosovo \\ ${ }^{3}$ Department of Veterinary Medicine, Faculty of Agriculture and Veterinary, University of Prishtina, Prishtina, Kosovo \\ Email: ^njazi.bytyqi@uni-pr.edu, skender.muji@uni-pr.edu, agim.rexhepi@uni-pr.edu
}

How to cite this paper: Bytyqi, N., Muji, S. and Rexhepi, A. (2020) Consumer Behavior for Milk and Dairy Products as Daily Consumption Products in Every Household-The Case of Kosovo. Open Journal of Business and Management, 8, 997-1003. https://doi.org/10.4236/ojbm.2020.82063

Received: February 26, 2020

Accepted: March 28, 2020

Published: March 31, 2020

Copyright $\odot 2020$ by author(s) and Scientific Research Publishing Inc. This work is licensed under the Creative Commons Attribution International License (CC BY 4.0).

http://creativecommons.org/licenses/by/4.0/

\begin{abstract}
In our study, we used consumer behavior to study the buying and consuming patterns for milk and dairy products for households in Kosovo. The study uses data collected from consumers of milk and dairy products. Data obtained from the field were recorded and analyzed with the SPSS statistical program. The results of this study show that the date of production and the content of milk and dairy products are the most important factors that consumers consider when purchasing milk and dairy products. Moreover, supermarkets are the favorite place of supply for milk and dairy products for consumers. Consumers are most likely to buy milk and dairy products twice a week.
\end{abstract}

\section{Keywords}

Consumer Behavior, Milk and Dairy Products, Households, Market Research

\section{Introduction}

Based on data from the Ministry of Agriculture, Forestry and Rural Development in Kosovo, milk and dairy production is mostly based on milk production and dairy products from cows, which is the most important sector in livestock production in Kosovo (MAFRD, 2015) [1]. With the current number of dairy cows, it is estimated that Kosovo is able to cover $84 \%$ of the domestic market demand, and to meet local needs continues to import about $16 \%$ of milk and dairy products. In Kosovo, yearly consumption of milk and dairy products is estimated to be around $215 \mathrm{~kg} /$ per capita (MAFRD, 2015) [1]. The total market for

${ }^{*}$ Corresponding author. 
milk and dairy products in Kosovo is estimated at 441 thousand tons per year, including fresh milk, which includes all domestic production, import and export of milk and dairy products (MAFRD, 2015) [1]. Domestic production is estimated to be around 369,000 tons of cow's milk. In Kosovo, the total dairy consumption per capita is estimated to be 0.59 liters per day (MAFRD, 2015). Dairy products are one of the most important products of livestock and it can affect people's health (Rahnama \& Rajabpour, 2017) [2]. Recommendations for consumption of dairy products are 2 to 3 servings or cups of milk or other dairy products per day (Weaver, 2014) [3]. Energy, proteins, calcium, vitamins, cholesterol, riboflavin, carbohydrate and other useful nutrients are provided by dairy products (Dror \& Allen, 2013) [4]. The study of consumer behavior, helps dairy processing companies and organizations to improve their marketing strategies by the understanding of the issues such as consumers thinking, influence of the consumer by the environment or consumers shopping behavior (Kapsdorferova \& Nagyova, 2005) [5]. Consumer behavior involves the use and the disposal of products as well as the study of how they are purchased (George \& Michael, 1997) [6]. Consumer behavior is a study of the processes involved when individuals or groups select, purchase, use, or dispose of products, services, ideas, or experiences to satisfy needs and desires (Solomon, 1996) [7]. Consumer buying behavior was a relatively new field in the late 60s. This scientific discipline has emerged from other disciplines such as economics, marketing and behavioral sciences (Engel, Blackwell, \& Miniard, 1995) [8]. Consumer behavior has borrowed its concepts from the development of other scientific disciplines, such as psychology (study of the individual), sociology (study of groups), social psychology (study of how an individual operates in social groups), and anthropology (the impact of society on the individual) and economics (the study of patterns of spending in society) (Smith \& Rupp, 2003) [9]. The study of consumer behavior is quite complex, due to the many (variables) variables involved and their tendency to interact and influence one another (Gajjar, 2013) [10]. The family is considered to be one of the most important consumer buying groups in society (Ford, LaTour, \& Henthorne, 1995) [11]. For the behavior of consumers towards different products, different authors in several studies (Verbeke \& Viaene, 1998) [12], show that there are significant differences between the behaviors of consumers in different countries. Consumer behavior research enables better understanding and forecast not only of the subject of purchases, but also of the motives and frequency of purchasing (Stavkova, Stejskal, \& Toufarová, 2008) [13]. Consumers often use the image and economic development of a country as an indicator of product features that are difficult to visualize, the psychological factor is also a factor influencing consumer behavior (Ford, LaTour, \& Henthorne, 1995) [11]. It is important to study factors stimulating and influencing consumers when purchasing milk products in order to support their consumption as well as to study factors that prevent consumers in their purchasing and consumption in order to deal with them and eliminate them if possible (Kuraj- 
dova, Táborecká-Petrovipová, \& Kašpáková, 2015) [14].

\section{Materials and Methods}

The basis of this study was interviews and data collection with consumers of milk and dairy products, with the method of meeting directly with consumers, also by consulting the relevant literature of the similar field (consumer behavior). In the framework of the working methodology for the design of the study, we have used these methods: the method of analysis, the method of comparison, the descriptive method as well as the empirical method. This study is based on 699 interviews conducted with consumers of milk and dairy products. The data received from the interviewers were recorded at the time of the questionnaire at the same time. After conducting all interviews with consumers, their data were recorded in a database and were analyzed with statistical package SPSS.

\section{Results and Discussion}

The data in Table 1, present the effects of factors influencing consumer behavior when purchasing milk and dairy products. Referring to these data, product quality is shown to be a very important factor with $60.7 \%$ of the impact on consumers when consuming milk and dairy products, followed by product safety and price of product as a moderately important factor with $47.2 \%$ of influencing. While factors such as: brand (82.2\%), packaging $(88.2 \%)$, origin $(80.7 \%)$ and product content (88.1\%) have not been shown to be important factors affecting consumers, in the purchasing determination and consumption of milk dairy products.

The results from Table 2, show that $85.2 \%$ of consumers claim that the date of product production is the factor that mostly cares consumers when buying milk and dairy products, followed by the product composition, as a factor important with $40.3 \%$ of estimates of consumers when buying milk and dairy products. Brand and the origin of the product, did not have shown any particular attention to consumers as important factors, when buying milk and dairy products.

The most favored places from consumers, for the purchase of milk and dairy products are supermarkets with $55.7 \%$ of their preferences, followed by their preference for buying in the green market by $18.8 \%$ of the consumer's declarations.

Table 1. Influencing factors of consumers, when buying milk and dairy products.

\begin{tabular}{cccccccc}
\hline Description & $\begin{array}{c}\text { Quality } \\
\%\end{array}$ & $\begin{array}{c}\text { Safety } \\
\%\end{array}$ & $\begin{array}{c}\text { Price } \\
\%\end{array}$ & $\begin{array}{c}\text { Brand } \\
\%\end{array}$ & $\begin{array}{c}\text { Packing } \\
\%\end{array}$ & $\begin{array}{c}\text { Origin } \\
\%\end{array}$ & $\begin{array}{c}\text { Product } \\
\text { composition \% }\end{array}$ \\
\hline Very important & 60.7 & 21.8 & 7.1 & 0.7 & 0.4 & 8.2 & 8.8 \\
$\quad$ Important & 18.7 & 47.2 & 9.7 & 3.3 & 2.9 & 4.8 & 1.9 \\
A little bit important & 3.6 & 6.3 & 47.2 & 13.8 & 8.5 & 6.3 & 1.2 \\
Not important & 17.0 & 24.7 & 36.0 & 82.2 & 88.2 & 80.7 & 88.1 \\
Total (\%) & 100 & 100 & 100 & 100 & 100 & 100 & 100 \\
\hline
\end{tabular}


While stores with $3.9 \%$ and outpatient retailers $4.6 \%$ are less favored by consumers when buying milk and dairy products (Figure 1).

In Figure 2, the results show that $55.5 \%$ of consumers prefer to buy milk and dairy products, twice a week, followed by $22.0 \%$ of consumers to prefer to buy milk and dairy products once a week. From these results, we can point out that consumers in rare cases decide to buy milk and their products at least twice a month (3.2\%).

Hypothesis testing has been analyzed with the Che-Square test, results have shown that the effects of factors affecting consumers in buying and consuming milk and dairy products have given very significant results, which are presented in Table 3. The quality of milk and dairy products, show sensitive results compared

Table 2. The impact of factors on consumer care when purchasing milk and dairy products.

\begin{tabular}{ccccc}
\hline Description & $\begin{array}{c}\text { Production data } \\
\%\end{array}$ & $\begin{array}{c}\text { Product compositions } \\
\%\end{array}$ & $\begin{array}{c}\text { Brand } \\
\%\end{array}$ & $\begin{array}{c}\text { Origin } \\
\%\end{array}$ \\
\hline Not care & 0.9 & 0 & 5.4 & 0.7 \\
Careful & 1.0 & 12.0 & 31.1 & 35.7 \\
Average care & 3.5 & 25.0 & 36.6 & 19.9 \\
Good care & 9.4 & 40.3 & 12.1 & 21.4 \\
Very careful & 85.2 & 22.7 & 14.8 & 22.3 \\
Total $(\%)$ & 100 & 100 & 100 & 100 \\
\hline
\end{tabular}

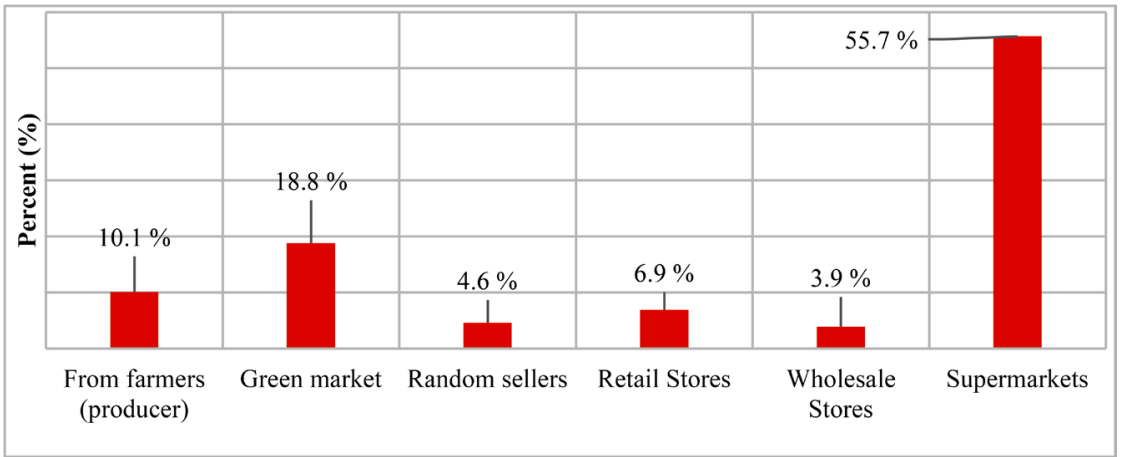

Figure 1. The place where consumers buying milk and dairy products.

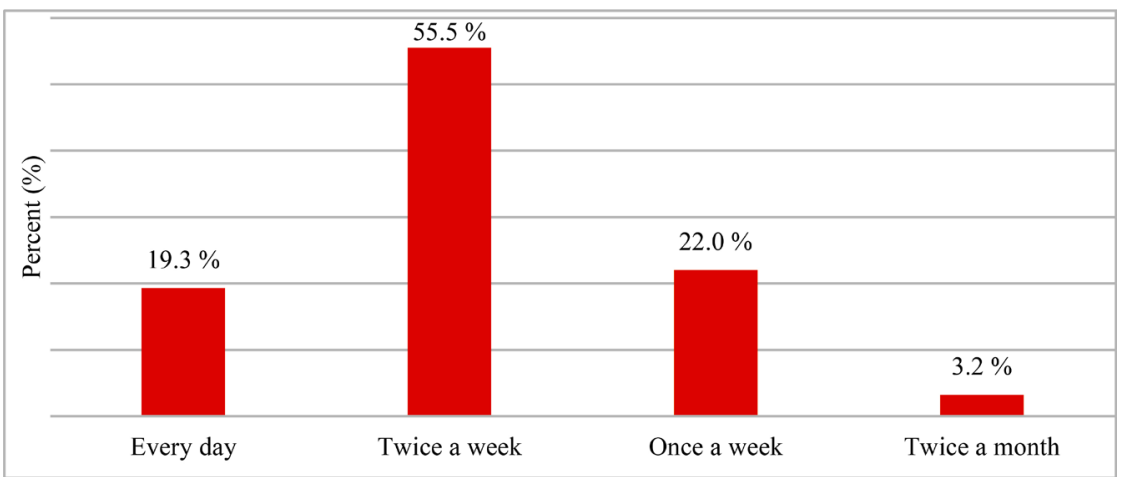

Figure 2. Frequency of purchasing milk and dairy products from consumers. 
Table 3. Level of significance, when consumers buying milk and dairy products.

\begin{tabular}{cccccc}
\hline Description & Quality & Safety & Price & Brand & Packing \\
\hline Gender of consumers & $0.949^{*}$ & $0.188^{*}$ & $0.317^{*}$ & $0.272^{*}$ & $0.469^{*}$ \\
Employment & $0.161^{*}$ & $0.082^{*}$ & $0.716^{*}$ & $0.185^{*}$ & $0.933^{*}$ \\
Education & $\mathbf{0 . 0 0 3 ^ { * * }}$ & $\mathbf{0 . 0 1 2 ^ { * * }}$ & $0.304^{\star}$ & $\mathbf{0 . 0 0 1 ^ { * * * }}$ & $0.739^{*}$ \\
The average income in the family & $\mathbf{0 . 0 0 1 ^ { * * * }}$ & $0.172^{*}$ & $0.459^{*}$ & $\mathbf{0 . 0 3 0 ^ { * * }}$ & $0.096^{*}$ \\
The age & $\mathbf{0 . 0 0 4 ^ { * * * }}$ & $0.086^{*}$ & $0.765^{*}$ & $0.120^{*}$ & $0.611^{*}$ \\
Number of members in the family & $0.504^{*}$ & $0.257^{*}$ & $0.489^{*}$ & $\mathbf{0 . 0 3 0 ^ { * * }}$ & $0.074^{*}$ \\
$\begin{array}{c}\text { Number of members employed } \\
\text { in the family }\end{array}$ & $\mathbf{0 . 0 4 4 ^ { * * * }}$ & $\mathbf{0 . 0 0 5 ^ { * * * }}$ & $0.720^{*}$ & $\mathbf{0 . 0 0 4 ^ { * * * }}$ & $0.027^{*}$ \\
\hline
\end{tabular}

${ }^{\star} \mathrm{P}<0.05$ No significant, ${ }^{\star *} \mathrm{P}<0.01-$ Significant and ${ }^{\star *} \mathrm{P}<0.001-$ Very Significant, Chi-square test.

to the level of consumer education with $0.003(\mathrm{P}<0.001)$ significant level. Average consumer income relative to the quality of milk and dairy products in relation to quality of product, have shown significant level with $0.004(\mathrm{P}<0.001)$. The quality of milk and dairy products has also shown a level of significant in relation to the number of family members employed with $0.044(\mathrm{P}<0.01)$ significant levels. The ratio between the number of family members with the brand of product has yielded significant results of $0.030(\mathrm{P}<0.01)$. The number of family members employed in relation to the brand of product has given a significant result of $0.004(\mathrm{P}<0.001)$ sensitivity level. All this data on the level of consumer sensitivity in relation to the factors affecting the consumption and purchase of dairy and dairy products have been confirmed according to the hypotheses raised in this study.

\section{Discussion of Results}

Based on the data in this study, proved that of milk and dairy products prefer to consume to all families Kosovar. Results of this study (Table 1), show its factors such as quality, safety and price are very important factors impacting the purchase of milk and dairy products from consumers. While factors like the brand, packaging, product composition, are not shown to be very important factors affecting to consumers, in the purchasing determination and consumption of milk and dairy products, therefore the influence of these factors (brand, packaging, product composition) is moderately influential on consumers in the purchase of milk and dairy products. The date of production and the content of dairy products have been shown to be the most important factors that consumers pay attention when buying milk and dairy products for consumption in their families. Results are comparable with a study of Bytyqi et al. (2008) [15], where factors that are considered to be very important are: quality, safety, price and origin of the product. While other factors such as brand name, packaging, and packaging were rated as minor, and in most cases not significant. Consumers pay more attention to milk and dairy products, the date of manufacture and the origin of the 
products, which are valued more carefully, whereas the contents of the packaging of the product and the name of the manufacturer do not pay much attention. The location most frequented/preferred by consumers to buy milk and dairy products has been shown to be a supermarket (55.7\%). The results show that the frequency of consumers buying milk and dairy products is: twice a week, once a week and twice a month.

\section{Conclusion and Recommendations}

The concept of consumer behavior in the Kosovo market has begun to be used by traders as an instrument to offer consumers desirable, quality, safe and competitive products on the market. Influences of factors on consumer behavior, such as quality, safety and price, presented in our study, have given significant effect to this scientific discipline in the Kosovo market. Consumer behavior during purchasing and consumption of dairy and dairy products in Kosovo is influenced by a large number of factors such as employment, education, age, household income, number of family members. These factors directly affect consumer's behavior when buying milk and dairy products.

\section{Conflicts of Interest}

The authors declare no conflicts of interest regarding the publication of this paper.

\section{References}

[1] MAFRD Ministry of Agriculture Forestry and Rural Development, Department of Economic Analyzes and Agricultural Statistics (2015) Report Milk Market Analysis in Kosovo. Pristina, 2-24.

[2] Rahnama, H. and Rajabpour, S. (2017) Factors for Consumer Choice of Dairy Products in Iran. Appetite, 111, 46-55. https://doi.org/10.1016/j.appet.2016.12.004

[3] Weaver, C.M. (2014) How Sound Is the Science behind the Dietary Recommendations for Dairy. The American Journal of Clinical Nutrition, 99, 1217-1222. https://doi.org/10.3945/ajcn.113.073007

[4] Dror, D.K. and Allen, L. (2013) Dairy Product Intake in Children and Adolescents in Developed Countries: Trends, Nutritional Contribution, and a Review of Association with Health Outcomes. Nutrition Reviews, 72, 68-81. https://doi.org/10.1111/nure.12078

[5] Kapsdorferova, Z. and Nagyova, L. (2005) Consumer Behavior at the Slovak Dairy Market. Agricultural Economics-Czech, 8, 362-368. https://doi.org/10.17221/5120-AGRICECON

[6] George, B. and Michael, B. (1997) Advertising and Promotion: An Integrated Marketing Communications Perspective. McGraw-Hill, Boston.

[7] Solomon, M. (1996) Consumer Behavior: Buying, Having, and Being. Prentice-Hall, Upper Saddle River.

[8] Engel, J., Blackwell, R. and Miniard, P. (1995) Consumer Behavior. Dryden Press, Chicago, New York.

[9] Smith, A. and Rupp, W. (2003) Strategic Online Customer Decision Making: Leve- 
raging the Transformational Power of the Internet. Online Information Review, 27, 418-432. https://doi.org/10.1108/14684520310510055

[10] Gajjar, N. (2013) Factors Affecting Consumer Behavior. International Journal of Research in Humanities and Social Sciences, 2, 10-15.

[11] Ford, J., LaTour, M. and Henthorne, T. (1995) Perception of Marital Roles in Purchase Decision Processes: A Cross-Cultural Study. Journal of the Academy of Marketing Science, 23, 120-131. https://doi.org/10.1177/0092070395232004

[12] Verbeke, W. and Viaene, J. (1998) Consumer Behaviour towards Yoghurt in Belgium and Poland: A Survey in Two Regions. British Food Journal, 100, 201-207. https://doi.org/10.1108/00070709810207883

[13] Stavkova, J., Stejskal, L. and Toufarová, Z. (2008) Factors Influencing Consumer Behaviour. Agricultural Economics (AGRICECON) - Czech, 54, 276-284. https://doi.org/10.17221/283-AGRICECON

[14] Kurajdova, K., Táborecká-Petrovipová, J. and Kašpáková, A. (2015) Factors Influencing Milk Consumption and Purchase Behavior-Evidence from Slovakia. Procedia Economics and Finance, 34, 573-580. https://doi.org/10.1016/S2212-5671(15)01670-6

[15] Bytyqi, H., Vegara, M., Gjonbalaj, M., Mehmeti, H., Gjergjizi, H., Miftari, I., et al. (2008) Analysis of Consumer Behavior in Regard to Dairy Products in Kosovo. Agricultural Research, 46, 311-320. 